(2) Open Access Full Text Article

\title{
Neuropsychological profiles of members of organized crime and drug-traffic organizations
}

This article was published in the following Dove Press journal:

Research and Reports in Forensic Medical Science

16 October 2012

Number of times this article has been viewed

\section{Feggy Ostrosky \\ Karina Cecilia Borja \\ César Romero Rebollar \\ Karla Ximena Díaz Galván \\ Laboratory of Neuropsychology and Psychophysiology, National \\ Autonomous University of Mexico, Mexico City, Mexico}

Correspondence: Feggy Ostrosky Laboratory of Neuropsychology and Psychophysiology, National Autonomous University of Mexico,

Mexico City, Mexico

Tel +52555622 2327

Email feggy@unam.mx
Abstract: Members of organized crime and drug traffic organization have developed a hierarchical model of association while participating in the production, distribution, and commercialization of drugs and defense of their territory. The nature of these organizations leads to extremely violent acts, similar to those performed by psychopathic delinquents. Eightytwo incarcerated male offenders - members of these organizations - were assessed and later classified according to the role they played in the organization: kingpins, money launderers, protectors, enforcers, and distributors/producers. These individuals were paired to a control group of 76 nonincarcerated healthy male volunteers from a community sample. We obtained their psychopathic profile and frontal lobe functioning using the Psychopathy Checklist, Revised (PCL-R), PCL-R score, and the Frontal Lobe and Executive Functions Battery. Kingpins and enforcers were considered as psychopaths across the entire range, while the money launderers fit in the description of successful psychopathy, and interesting contrasts were observed within the groups in the PCL-R factors. The orbitofrontal cortex was the functional area affected in the inmate sample, being more detrimentally affected in the most violent samples, thus providing a useful measure of psychopathy and violence of unimpaired criminals. An objective classification of incarcerated criminals will allow us to distinguish between neuronal and cultural psychopaths and sociopaths, which will help us establish adequate readaptation programs. Social issues were also determinants: it was found that in the environment where these criminals grew up, there is a broad acceptance and validation of lifestyles characterized by the accumulation and showing off of material values over intellectual and social values, which in addition to drug consumption trigger the development of aggressive and violent personalities. Readaptation programs must strengthen cognitive abilities, which are normally diminished in these individuals, and encourage a lifestyle with an "integral wealth perspective" that values not only economic but also personal, social, familial, labor, and cultural assets.

Keywords: psychopathy, violence, executive functions, orbitofrontal regions

\section{Introduction}

Violence is a worldwide problem, but during the last few years Mexico has been particularly violent because of its war against drugs and the constant clashes among drug cartels, which had resulted in more than 35,000 deaths between 2006 and $2011 .^{1}$ This problem is already a national security matter due to various factors: the geographic space occupied by Mexico, which has allowed it to emerge as one of the main routes for drug smuggling into the US; the decline of Colombian cartels during past decades; and the subsequent increase of marijuana and amphetamine production. Cook $^{2}$ estimates the amount of money generated by drug traffic to be between US\$8.3 billion and $\$ 24$ billion. 
Such enormous profits have favored the proliferation of criminal organizations involved in drug trafficking - also named cartels - and smaller gangs or "cells" associated with them. These cartels have reached a significant level of logistics in regard to their structural organization and functioning, as they emerge as an attractive lifestyle to young, poor people with limited social and economical opportunities. ${ }^{3}$ The violence used by these gangs goes from the possession and use of numerous weapons aimed for military use only, including those for the US military forces, to the use of torture, mutilation, and decapitations in public places, and frequently victimizing civilians. Violent attacks are carefully planned and aimed at other cartels or cells for personal vendettas and territorial rivalry, or to threaten security members within the area and local and federal governments. ${ }^{1}$

Considering the series of violent events related to drug trafficking, we consider that the main goals of these cartels and related cells are the production, trafficking, and commercialization of illegal drugs, the protection of their present territory of operation and its expansion, and the increase of monetary profits by illegal actions indirectly connected to drug traffic: kidnapping, extortions, thievery, and fraud, amongst others.

Although these criminal organizations may vary in terms of the size of their cells and membership, they share a hierarchical structure in that they are established and led by a "kingpin," assisted by cell chiefs or "lieutenants" whose main function is to supervise different geographical areas. Cartels are administered by money launderers who may own an enterprise and benefit from illegal investments, or have the professional skills to create phantom enterprises that run and generate profits derived from drug traffic. Also, individuals with public duties (ie, policemen, mayors, municipal chairpersons, governors) may participate by falling into acts of corruption and providing "protection" to cartels, thus facilitating their operation by different means. The enforcers ("sicarios" in Spanish) are individuals in charge of the execution of violent actions such as attacks, homicides, kidnappings, and torture ordered by kingpins or cell leaders. Additionally, members in charge of the distribution and production of marijuana, opiates, cocaine, and amphetamines appear at the lowest hierarchical level. A proposed hierarchical diagram of cartels is shown in Figure 1.

Different areas within neuroscience have focused on the study of violent and delinquent behavior, concluding that most of the criminals present antisocial personality disorder (or sociopathy) and/or psychopathy. ${ }^{4,5}$ According to the fourth edition of the Diagnostic and Statistical Manual of

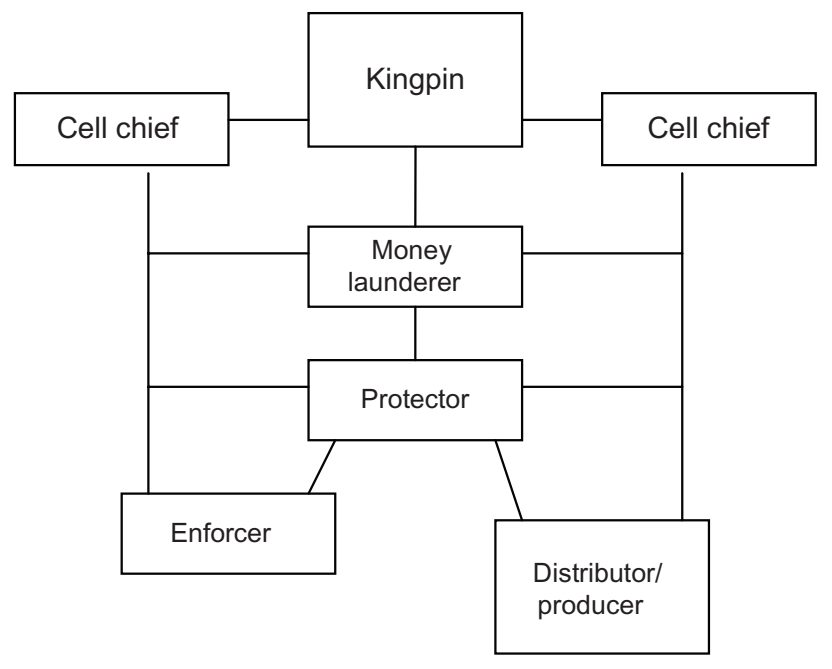

Figure I Primary hierarchical structure of Mexican drug cartels.

Mental Disorders (DSM-IV), ${ }^{6}$ sociopathy is considered a personality disorder and it is characterized by a generalized pattern of disregard and violation of the social rules and rights of others, beginning at least at 15 years of age. Individuals presenting these disorders show impulsivity, irresponsibility, lack of planning, mood changes, an increased need for immediate gratification, aggressiveness, and a low tolerance for frustration. ${ }^{7}$ However, psychopathy differs from antisocial personality disorder in that psychopaths can elicit both reactive and proactive aggression by using manipulation, glibness, callousness, and a lack of empathy and guilt that allows them to reach their goals despite all costs. Previous studies have found that between $1 \%$ and $3 \%$ of the population and $15 \%-25 \%$ of inmates qualify as psychopaths. ${ }^{8,9}$

Tovar and Ostrosky ${ }^{10}$ make an etiological distinction between psychopathy and sociopathy, and conclude that psychopathy has a predominantly genetic origin, ${ }^{11,12}$ whereas sociopathy is mainly acquired ${ }^{13-15}$ and can be subsequent to neural damage or to environmental conditions. They state that "neuronal sociopathy" results from brain damage or accidents (ie, tumors, neurovascular diseases, neuronal detriments, or traumatic brain injuries) in the frontal lobe, and specially within the ventromedial region of the prefrontal cortex. ${ }^{13,16}$ Conversely, "cultural sociopathy" may be acquired following detriments to the individual's psychosocial structure at vulnerable ages that facilitate his/her incorporation into a delinquent lifestyle, ${ }^{17}$ as recently portrayed by the Mexican child killer known as "El Ponchis."”

Structural detriments within the frontal lobe have been found in "successful" psychopaths or psychopathic individuals without a history of arrests, and violent individuals presenting antisocial personality disorder show decreases in prefrontal cortex volume, ${ }^{18,19}$ an asymmetrical anterior hippocampus, ${ }^{20}$ 
and a negative correlation between the volume of the amygdala and the level of psychopathy. ${ }^{21}$ Moreover, functional detriments such as reduced prefrontal activity and an increased activity in limbic areas have been found in impulsive killers. ${ }^{22}$

Neuropsychological studies have identified possible affected areas in the frontal lobe, where psychopaths and individuals presenting acquired sociopathy have shown a deficient performance on decision making, go/no go, odor identification, Stroop effect, and Hanoi Tower tests, ${ }^{23-26}$ pointing to ventromedial and orbitofrontal dysfunctions. However, there is disagreement regarding the participation of the dorsolateral prefrontal area. ${ }^{25,27,28}$ A recent study in a Mexican sample compared the neuropsychological performance of inmates with and without psychopathic traits to a control group. Significant differences in attention, visuospatial and verbal memory, inhibition, and decision-making were found between the two, with psychopaths performing at a much lower level. Additionally, a negative correlation was found between these traits, as measured by the Psychopathy Checklist, Revised (PCL-R) ${ }^{29}$ in both dorsolateral and orbitofrontal functions, thus the higher the affective, social deviation, and psychopathy scores, the lower the neuropsychological performance. ${ }^{30}$

Recently, it has been suggested that genetic factors explain between $38 \%$ and $69 \%$ of the variance of a type of antisocial behavior - drug-selling - which represents a significant social problem that contributes to an increase in crime, victimization, and a reduction in public health. At the individual level, it seems that genetics correlates with the environment in at least two different ways. (1) The passive gene-environment correlation that captures the fact that parents pass along two entities to their children: a rearing environment and a genotype. Because both the rearing environment and genotype are traced to the same source, they are bound to be correlated to some degree. And (2) the active gene-environment correlation, which has direct application to antisocial behaviors such as drugselling. This type of correlation avers that genetic factors are instrumental in pushing or nudging a person to select one environment over another. This type of gene-environment correlation entails with the criminological concept of selection, wherein individual-level factors are responsible for why people self select into certain environments. ${ }^{31}$ Therefore, although not all antisocial behaviors are influenced in the same way by genetic factors, involvement in organized crime and the role that the individual plays within the criminal organization could be related to biological factors such as integrity of brain structures, expressed as differences in the neuropsychological profile, that underlie both the behavioral control and antisocial and psychopathic personality that are considered predictors of criminal behaviors.

Considering all the findings and contradictions regarding the frontal functioning detriments of individuals presenting antisocial personality disorders and/or psychopathy, ${ }^{25,27,32}$ we believe that studying criminals presenting either one or both disorders and different typologies would allow a better depiction of their cognitive profile. Drug cartels and the organizational hierarchy of their members provide a valuable opportunity to study the neuropsychology of violent behavior. The goal of this study was to describe a large sample of incarcerated serious offenders who had performed defined roles in Mexican drug gangs, in relation to PCL-R scores and an array of cognitive neuropsychology assessments of prefrontal functioning.

\section{Materials and methods Participants}

An initial comprehensive review of 250 case files of inmates in high-security prisons in Mexico was carried out in order to select those accused of drug traffic and/or organized crime. A total of 101 individuals were eligible for assessment. Inclusion criteria were the absence of any psychiatric, medical, or neurological disorder, of any significant visual or auditory illness, of severe traumatic brain injury with loss of consciousness, absence of drug consumption in the last 6 months and Spanish as their native language. Each participant signed a written consent confirming their voluntary participation. Absolute confidentiality was assured, and they were also assured that obtained data would not interfere with their judicial trial or sentence. Ten inmates refused to participate, six did not comply with the inclusion criteria, and three were on a judicial trial. Thus, the final sample consisted of 82 inmates pertaining to different hierarchical levels in terms of positions and functions in criminal organizations related to drug production, trafficking, and marketing. As a result, six groups were formed, depending on their main activity in the cartel by the time of their imprisonment. Figure 1 illustrates the model that describes the behavior of each of the members of organized crime.

\section{Kingpins}

The kingpin is defined as the founder or chief of either a criminal organization or a small subordinate cell, who makes decisions on its structure, functioning, and logistics. He has committed violent acts and orders assaults or murders to rival cartels, and negotiates territories and plans routes of distribution. Typically, he seeks the cooperation of security and corrupt government authorities. 


\section{Money launderers}

These are the people who administer the financial profits of criminal organizations and/or cells. They usually manage a phantom or fake enterprise funded by illegal resources.

\section{Protectors}

Protectors are defined as corrupt government employees (federal and municipal police, federal agents and officers, commanders, lieutenants, attorneys) and people whose job facilitates the operation of criminal organizations in exchange for high-value yet illegal rewards (eg, customs-house workers, who do not necessarily achieve high education levels to get their employment). They may give advice on special surveillance programs, protect the drug traffic up to its final destination, hide incriminating evidence when delinquents are caught, accept money for releases, avoid arrests, and even reduce judicial sentences.

\section{Enforcers}

Also known as "hitmen" or "sicarios," these are the individuals in charge of committing highly violent acts aimed at rival cartels or any other person who interferes with the activity of the gang. They may assassinate, kidnap, torture, or even perpetrate public violent acts against civil society as a revenge for a prior act (ie, capture).

\section{Distributors and/or producers}

This category refers to individuals in charge of the production and distribution of marijuana, opiates, cocaine, amphetamines, etc, or of distribution in a specific geographic area.

\section{Control group}

The control group consisted of 76 healthy male volunteers from a community sample. These individuals had no history of convictions, arrests, head trauma, medical or neurological conditions, use of drugs, or history of DSM-IV axis I disorders, psychiatric or neurological diseases. All subjects signed an informed consent and participated in an interview that included personal history and a psychiatric assessment using the Mini-International Neuropsychiatric Interview. $^{33}$

\section{Materials}

\section{Psychological assessment}

- Semistructured interview: Adapted from Hare's interview to detect psychopathy, ${ }^{8,29}$ focused on family history, education, personal relationships, work history, and other questions related to juvenile delinquency and criminal career and psychopathic traits.

- File review: A comprehensive review of the files provided by the prison authorities, containing medical examination records, including mental health, criminal initiation and development, violence history, modus operandi, use of weapons, capture, and behavior during imprisonment, among others. Together with the interview, this helped to determine the presence of psychopathy.

- PCL-R: ${ }^{8,29}$ This is a 20 -item, three-point scale (0-2); total scores can range from 0 to 40 and reflect the degree to which the person matches the psychopathy construct. Items can be arranged in two factors. Factor 1 (F1) reflects the interpersonal and affective core components of the disorder, such as cruelty, lack of empathy, manipulation, glibness, shallow affect, and irresponsibility for actions. Factor 2 (F2) reflects a socially deviant lifestyle, characterized by a lack of realistic long-term goals, a need for constant stimulation, impulsivity, juvenile delinquency, and criminal versatility. Scores equal to or above 23 in inmate populations are related to a high degree of psychopathy. ${ }^{20,34}$ In a Brazilian sample, this cutoff score presented a sensitivity level of $84.8 \%$ and specificity of $100 \% .{ }^{35}$ The PCL-R was recently standardized in a Mexican inmate population. ${ }^{9}$

\section{Neuropsychological assessment}

- Executive Functions Battery ${ }^{36}$ (BANFE): This is comprised of 15 subtests that assess frontal and executive functions related to orbitofrontal, dorsolateral, and anterior prefrontal cortices. The Orbitofrontal Index measures inhibitory control, incorporation of social rules, and following up of instructions as well as risk/benefit processing; the Dorsolateral Index measures visuospatial and verbal working memory, mental flexibility, verbal fluency, and planning; while the Anterior Prefrontal Index measures metacognition, categorization, abstract reasoning, and problem-solving. In summary, the executive functions are a complex construct related to the control, regulation, and planning of human behavior, facilitating the individual's involvement in independent and professional activities, which are of vital importance for personal development and socialization. ${ }^{37}$ Norms by age and educational level were obtained in a Spanish-speaking population of 500 healthy participants ranging from 6 to 85 years of age with 4-20 years of education. Performance is based on a mean of 100 (standard deviation of 15) and allows classification 
into high performance (above 116), normal performance (85-115), mild to moderate deficits (70-84) and severe detriments (less than 69). It is worth noting that all the instruments are standardized in a Spanish-speaking population according to age and educational level; consequently, data from the inmate group was compared with the norms and to the control group.

\section{Data analyses}

The program SPSS 17 (IBM, Armonk, NY) was used for the statistical analyses. A descriptive characterization of the sample by mean and range was obtained. One-way analyses of variance were carried out to compare the age, education years, and the scores obtained from the BANFE between the control and inmate groups, as well as between the different inmate groups. To further assess differences between groups in all our measures, Bonferroni post hoc correction tests were carried out using a significance level equal to or below 0.05. Also, Pearson's correlation analysis was conducted to observe if the PCL-R total score as well as F1 and F2 were correlated to the BANFE total score and subindexes.

\section{Procedure}

The protocol was approved by the prison authorities with expertise in experimental protocol; it consisted of three sessions of 2.5 hours each. A quiet area was assigned within the prison for the assessment of the inmate group; guards were in charge of accompanying participants to the assessment room and back to their cells. The control group was assessed at the Laboratory of Neuropsychology and Psychophysiology in the Faculty of Psychology at the National Autonomous University of Mexico.

Assessments were carried by five psychologists trained in the identification of psychopathic traits and sociopathy using the PCL- ${ }^{8}$ and who participated in its standardization in a Mexican inmate population. ${ }^{9}$ Additional sources of information were used to obtain the psychopathy score.
For each case, two different raters independently coded the PCL-R protocol. An inter-rater score of 0.90 was obtained for the total PCL-R, 0.91 for F1 and 0.89 for F2.

In order to determine the inclusion of inmates in the study and before the first session, criminological case files were provided by the institution and extensively revised in order to select those undergoing a judicial trial related to or accused of drug trafficking and/or organized delinquency, and each selected case was subsequently assigned to one of the aforementioned six groups.

During the first session, a semistructured interview (as proposed by Hare $)^{8,29}$ was carried out. A clinical history was conducted to obtain details about the life history of the participant and/or to dismiss those with neurological and psychiatric conditions. If participants complied with the inclusion criteria, then the Early Trauma Inventory ${ }^{38}$ was used. During the second and third sessions, the BANFE was used.

\section{Results}

Individuals affiliated with ten of the main cartels, currently operating or that used to operate in Mexico, were identified. The cartels were Sinaloa, Golfo, Juárez, Tijuana, Beltrán, La Familia, Amezcua, Zhen Li Ye Gon, Milenio, and Guadalajara. The average sentence was 32 years and time served $6 \pm 4$ years.

Descriptive statistics by age and role in the organization are presented in Table 1. Overall, the average age of the sample was 44 years $( \pm 9)$, range $26-64$. The average years of education were $12( \pm 4)$, range of $1-20$, which is equivalent to high school. It is worth noting that $80 \%$ of the sample reported that their education years prior to incarceration ranged from 6 to 9 , which is equivalent to elementary to junior high school, but that they were completing the next stage in prison. No significant differences were found in ages, but significant differences were found in the education years of the money launderer $(14 \pm 3$,

Table I Descriptive statistics of the sample according to their function in the criminal organization

\begin{tabular}{|c|c|c|c|c|c|c|c|c|}
\hline \multirow[t]{2}{*}{ Group } & \multirow[t]{2}{*}{$\mathbf{n}$} & \multicolumn{2}{|c|}{ Age, years } & \multirow[t]{2}{*}{$P$} & \multicolumn{2}{|c|}{ Education, years } & \multirow[t]{2}{*}{$P$} & \multirow[t]{2}{*}{ Sig dif } \\
\hline & & $X(S D)$ & Range & & $X(S D)$ & Range & & \\
\hline Controls & 76 & $42(8.5)$ & $22-60$ & NS & $12.7(3)$ & $6-20$ & NS & - \\
\hline Inmates & 82 & $44(9)$ & $26-64$ & NS & $12(4)$ & $\mathrm{I}-20$ & NS & - \\
\hline Kingpins & 30 & $45(9)$ & $34-64$ & NS & $10(3)$ & $3-17$ & 0.01 & vs $\mathrm{L}$ \\
\hline Money launderers & 12 & $44(10)$ & $31-62$ & NS & $14(3)$ & $9-18$ & 0.02 & vs K \\
\hline Enforcers & 14 & $43(10)$ & $31-62$ & NS & II (4) & $1-17$ & NS & - \\
\hline Protectors & 6 & $43(10)$ & $26-64$ & NS & $15(3)$ & $\mathrm{I}-20$ & NS & - \\
\hline Distributors/producers & 21 & $42(9)$ & $26-58$ & NS & $12(4)$ & $5-17$ & NS & - \\
\hline
\end{tabular}

Abbreviations: K, kingpins; L, money launderers; NS, not significant; Sig dif, significant differences; SD, standard deviation; $X$, arithmetical mean. 
range 9-18) and the kingpin groups (10 \pm 3 , range 3-17). Through the direct interview, it was revealed that the vast majority of incarcerated offenders $(>85 \%)$ belonged to a primary family group of low socioeconomic income and also that the main reason for dropping out of school was to contribute to the family expenses and/or to improve their socioeconomic level.

\section{Psychological assessment}

On the PCL-R, the inmate group scored significantly higher on the total score as well as in both factors, and a detailed group analysis showed contrasts among them. Overall, the inmates scored 21 on the total PCL-R ( \pm 6 , range 10-36), while the control group scored $3( \pm 1$, range $0-8)$. In the interpersonal/affective component or F1, the inmate group had a score of $11( \pm 3$, range $3-16)$ and the control group scored $1( \pm 0.4$, range $0-3)$. In the antisocial lifestyle component or $F 2$, the inmate group scored 7 ( \pm 4 , range $2-16)$, and the control group scored $2( \pm 0.6$, range $0-5)$.

For psychopathy level, the enforcers had the highest score (24), followed by the kingpins (23), distributors/producers (21), protectors (18), and money launderers (17). A cutoff of 23 has been accepted to classify participants as psychopaths in previous inmate population studies; ${ }^{20,34}$ based on this, both the enforcers and kingpins may be considered as such. Four out of 14 enforcers (29\%), six out of 29 kingpins (21\%), eight out of 28 money launderers (32\%), five out of ten protectors $(50 \%)$, and seven out of 22 distributors/producers (31.6\%) were classified as having a medium-high psychopathy level.
In the interpersonal/affective component or F1, the enforcers, kingpins and money launderers presented higher scores than the other groups, and were statistically different from the distribution/production group. In the antisocial lifestyle component or F2, the enforcers, kingpins and distributors/producers showed higher scores than the money launderers. These results are presented in Table 2.

\section{Neuropsychological assessment}

Statistical differences were found between the control group and the enforcers in the BANFE total score, and in the Orbitofrontal Index between the control and both the enforcer and the distributor/producer groups.

In the Orbitofrontal Index, the kingpins and launderers had mean scores of 97 and 98, respectively; the protectors had a score of 86 points, which may be considered a relatively normal-low performance; and the distributors/producers and enforcers had scores of 83 and 81, respectively, which are considered as in the mild-alteration range. The Stroop effect was highly sensitive, as the controls, kingpins, and launderers had significantly higher scores than the enforcers, who in turn committed more errors than the rest of the groups, except for the distributors/producers. Additionally, the inmate group had a significantly lower performance in the gambling task (see Table 3).

In the Anterior Prefrontal Index, the launderers had a score of 112, which could be considered in the normal-high range; the kingpins and distributors/producers had a normal performance of 104 and 102, respectively, and the protectors

Table 2 Mean average and range of the PCL-R score, factor I (affective/interpersonal) and factor 2 (antisocial lifestyle by function in the criminal organization)

\begin{tabular}{|c|c|c|c|c|c|c|}
\hline Group & $\begin{array}{l}\text { PCL-R } \\
X \text { SD }\end{array}$ & P; Sig dif & $\begin{array}{l}\text { FI } \\
X \text { SD }\end{array}$ & P; Sig dif & $\begin{array}{l}\text { F2 } \\
X \text { SD }\end{array}$ & P; Sig dif \\
\hline \multirow[t]{6}{*}{ Controls } & $3(2)$ & $0.000 ;$ vs I & I (0.4) & $0.000 ;$ vs I & $2(0.6)$ & 0.000 ; vs C \\
\hline & & $0.000 ;$ vs $\mathrm{K}$ & & $0.000 ;$ vs $\mathrm{K}$ & & $0.000 ;$ vs $\mathrm{K}$ \\
\hline & & $0.000 ;$ vs L & & $0.000 ;$ vs L & & $0.046 ;$ vs $P$ \\
\hline & & $0.000 ;$ vs $P$ & & $0.000 ;$ vs $\mathrm{E}$ & & 0.000 ; vs Dp \\
\hline & & $0.000 ;$ vs $\mathrm{P}$ & & $0.000 ;$ vs $P$ & & $0.000 ;$ vs $\mathrm{E}$ \\
\hline & & $0.000 ;$ vs $D p$ & & $0.000 ;$ vs $D p$ & & \\
\hline Inmates & $21.2(5.9)$ & $0.000 ;$ vs C & $10.6(2.6)$ & $0.000 ;$ vs C & $7.5(3.6)$ & 0.000 ; vs C \\
\hline \multirow[t]{2}{*}{ Kingpins } & $23(5.6)$ & 0.000 ; vs C & $11.2(2.8)$ & $0.000 ;$ vs C & $8.1(3.3)$ & $0.000 ;$ vs C \\
\hline & & $0.003 ;$ vs L & & 0.006; vs Dp & & $0.002 ;$ vs L \\
\hline \multirow[t]{3}{*}{ Money launderers } & $17.4(3.3)$ & $0.000 ;$ vs C & II (2) & $0.000 ;$ vs C & $4.5(1.4)$ & $0.002 ;$ vs K \\
\hline & & 0.003 ; vs K & & $0.042 ;$ vs Dp & & $0.010 ;$ vs Dp \\
\hline & & $0.003 ;$ vs $\mathrm{E}$ & & & & $0.000 ;$ vs S \\
\hline \multirow[t]{2}{*}{ Enforcers } & $23.9(7.1)$ & 0.000 ; vs C & II.2(2.1) & $0.000 ;$ vs C & $9.2(4.9)$ & $0.000 ;$ vs $C$ \\
\hline & & $0.003 ;$ vs L & & $0.042 ;$ vs $D p$ & & $0.000 ;$ vs L \\
\hline Protectors & $17.6(3.2)$ & 0.000 ; vs C & $10.3(1.3)$ & $0.000 ;$ vs C & $5.5(2.8)$ & 0.046 ; vs C \\
\hline \multirow[t]{2}{*}{ Distributors/producers } & $19.9(5.5)$ & 0.000 ; vs C & $9.1(3)$ & 0.000 ; vs C & $7.8(3.1)$ & 0.000 ; vs C \\
\hline & & & & & & $0.010 ;$ vs L \\
\hline
\end{tabular}

Abbreviations: C, controls; Dp, distributors/producers; E, enforcers; FI, factor I; F2, factor 2; I, inmates; K, kingpins; L, money launderers; NS, not significant; P, protectors; $\mathrm{SD}$, standard deviation; Sig dif, significant differences; $\mathrm{X}$, arithmetical mean. 
Table 3 Orbitofrontal Index and tests

\begin{tabular}{|c|c|c|c|c|c|c|c|c|c|}
\hline & Controls & Inmates & Kingpins & $\begin{array}{l}\text { Money } \\
\text { launderers }\end{array}$ & Protectors & $\begin{array}{l}\text { Distributors/ } \\
\text { producers }\end{array}$ & Enforcers & $P$ & Sig dif \\
\hline BANFE total score & $102.9(14.2)$ & $95.3(14.7)$ & $98.9(14.6)$ & $102(15.7)$ & $89.1(19)$ & $92(10)$ & $85.6(11.1)$ & 0.02 & C vs E \\
\hline \multirow[t]{2}{*}{ Orbitofrontal Index } & $103.6(12.8)$ & $91.2(18.4)$ & $97.3(16.7)$ & $98.4(17.3)$ & $86.5(18.6)$ & $82.9(12.6)$ & $80.7(24.2)$ & 0.001 & C vs Dp \\
\hline & & & & & & & & 0.001 & C vs E \\
\hline \multicolumn{10}{|l|}{ Maze } \\
\hline Crossing & $0.38(0.34)$ & $1.3(0.2)$ & $0.43(I)$ & $0.58(1.2)$ & $0.67(1.2)$ & $1.5(1.5)$ & I.I (I.5) & 0.03 & Cvs I \\
\hline Stroop A & & & & & & & & 0.01 & C vs Dp \\
\hline Time & $80.2(23.3)$ & $89(28.3)$ & $89.5(28.6)$ & $88.2(16.4)$ & $84(28.4)$ & $82(26.3)$ & $102.2(40.9)$ & 0.05 & Cvs I \\
\hline \multirow[t]{5}{*}{ Interference } & $0.8(1.2)$ & $1.8(1.8)$ & $1.6(1.7)$ & I.I (I.I) & $0.8(0.8)$ & $1.9(2.1)$ & $3.4(1.6)$ & 0.001 & C vs I \\
\hline & & & & & & & & 0.001 & C vs $E$ \\
\hline & & & & & & & & 0.02 & $\mathrm{~K}$ vs $\mathrm{E}$ \\
\hline & & & & & & & & 0.01 & L vs $E$ \\
\hline & & & & & & & & 0.001 & $P$ vs $E$ \\
\hline Total score & $82.7(2)$ & 80.6 & $81.7(2.1)$ & $8 \mathrm{I} .7(2.1)$ & $79.8(2.6)$ & $80.9(2.8)$ & $78.2(3.4)$ & 0.01 & C vs $E$ \\
\hline \multicolumn{10}{|l|}{ Gambling task } \\
\hline \% disadv decks & $33.3(11.1)$ & $34.9(14.3)$ & 33.7 (I5.7) & $34.6(13.3)$ & $38.3(9.3)$ & $36.7(15)$ & $33.9(15.3)$ & NS & \\
\hline Total & $32.2(17.6)$ & $31.3(19)$ & $33.7(2 \mathrm{I} .5)$ & $35(19.2)$ & $30.8(14.5)$ & $27.5(19.3)$ & $25.8(13.7)$ & 0.01 & Cvs I \\
\hline \multicolumn{10}{|l|}{ WCST } \\
\hline Maintain err & $0.6(0.8)$ & $0.6(0.8)$ & $0.6(0.6)$ & $0.6(0.6)$ & $0.5(0.8)$ & $0.7(0.9)$ & $0.3(0.5)$ & NS & \\
\hline \multicolumn{10}{|l|}{ Stroop B } \\
\hline Interference & $0.8(\mathrm{I} .5)$ & I.7 (2.8) & I.6 (2.2) & $0.8(1.5)$ & $2(1.5)$ & $2.5(5)$ & I.6 (I.7) & NS & \\
\hline Score & 82.8 (3.6) & $82.2(2.8)$ & $82.3(2.2)$ & $83.1(1.5)$ & $81.6(1.6)$ & $81.3(5)$ & $82.3(1.7)$ & NS & \\
\hline
\end{tabular}

Note: Standard deviations are presented in parentheses.

Abbreviations: C, controls; Dp, distributors/producers; E, enforcers; I, inmates; K, kingpins; L, money launderers; NS, not significant; P, protectors; SD, standard deviation; Sig dif, significant differences; WCST, Wisconsin card-sorting test.

and enforcers had a normal score of 102 . In the metamemory task, the protectors had significantly more positive errors or an overestimation of their memory capacity in comparison to the control group (see Table 4).

In the Dorsolateral Index, no statistical differences were found between groups, and the controls, kingpins, launderers, protectors, and distributors/producers had normal scores (101.7, 90, 101, 92, and 96, respectively), while the enforcers scored 89 . With the exception of the money launderers, all the groups showed means that were substantially less than the controls.
The inmate group as an overall had a significantly low score on visual and visuospatial working memory and mental flexibility, while the enforcers committed more errors on the mental-flexibility task. These results are presented in Table 5 and Figure 2. The correlation analysis revealed that the PCL-R total score, F1, and F2 were negatively correlated with the Orbitofrontal Index $(\mathrm{r}=-0.33, P \leq 0.001 ; \mathrm{r}=-0.29$, $P \leq 0.002 ; \mathrm{r}=-0.32 ; P \leq 0.001$, respectively); and that the PCL-R total score and F2 were negatively correlated with the BANFE total score $(\mathrm{r}=-0.25, P \leq 0.01 ; \mathrm{r}=-0.24$, $P \leq 0.01$, respectively).

Table 4 Anterior Prefrontal Index and tests

\begin{tabular}{|c|c|c|c|c|c|c|c|c|c|}
\hline & Controls & Inmates & Kingpins & $\begin{array}{l}\text { Money } \\
\text { launderers }\end{array}$ & Protectors & $\begin{array}{l}\text { Distributors/ } \\
\text { producers }\end{array}$ & Enforcers & $P$ & Sig dif \\
\hline $\begin{array}{l}\text { Anterior Prefrontal } \\
\text { Index }\end{array}$ & $101.1(14.1)$ & $103.4(15.8)$ & $103.6(18.9)$ & $111.6(11)$ & $93(18)$ & $101.6(12.5)$ & $101.7(11.5)$ & NS & Sig dif \\
\hline \multicolumn{10}{|l|}{ Semantic classification } \\
\hline Abstract cat & $4.5(2.9)$ & $5.5(2.6)$ & $5(2.7)$ & $5.5(2.8)$ & $5.6(2.5)$ & $6(2.9)$ & $6(2.3)$ & NS & \\
\hline \multicolumn{10}{|l|}{ Proverbs } \\
\hline Time & 91 (48.8) & 90.1 (38.4) & $95.6(32.4)$ & $75.3(18.2)$ & $95.3(43.3)$ & $84(45.5)$ & $98.7(56)$ & NS & \\
\hline Score & $3.6(0.7)$ & $3.5(0.8)$ & $3.5(0.9)$ & $3.6(0.5)$ & $3.4(0.8)$ & $3.3(0.7)$ & $3.5(0.6)$ & NS & \\
\hline \multicolumn{10}{|l|}{ Metamemory } \\
\hline Understim & $2.3(2.1)$ & I.7 (I.7) & $2.3(2)$ & $0.6(0.5)$ & I.5 (I.9) & $\mathrm{I} .4(\mathrm{I} .3)$ & I.5 (I.5) & 0.02 & C vs $P$ \\
\hline Overstim & $2(1.8)$ & $2.9(2.1)$ & $2.2(2.1)$ & $2.4(1.6)$ & $4.6(1.2)$ & $3(1.7)$ & $4(2.8)$ & NS & \\
\hline
\end{tabular}

Note: Standard deviations are presented in parentheses.

Abbreviations: C, controls; NS, not significant; P, protectors; SD, standard deviation; Sig dif, significant differences. 
Table 5 Dorsolateral Index and tests

\begin{tabular}{|c|c|c|c|c|c|c|c|c|c|}
\hline & Controls & Inmates & Kingpins & $\begin{array}{l}\text { Money } \\
\text { launderers }\end{array}$ & Protectors & $\begin{array}{l}\text { Distributors/ } \\
\text { producers }\end{array}$ & Enforcers & $P$ & Sig dif \\
\hline Dorsolateral Index & $101.7(15)$ & $96.7(14.3)$ & $99.1(13.8)$ & $101(14)$ & $91.8(21.8)$ & $95.8(12.4)$ & $88.8(10.6)$ & NS & Sig dif \\
\hline \multicolumn{10}{|c|}{ Visual working memory } \\
\hline Persev err & $2.8(2.8)$ & $4.3(3.7)$ & $3.4(3.4)$ & $5.1(3.7)$ & $4.6(4.2)$ & $3.6(2.7)$ & $6.3(5.2)$ & 0.01 & C vs I \\
\hline Omission & $2.2(1.9)$ & $2.1(2.1)$ & $2.2(2.2)$ & $1.9(2)$ & $1.5(1.2)$ & $1.8(1.8)$ & $1.5(1.2)$ & NS & \\
\hline Time & $74.2(44.3)$ & $100.5(45)$ & $94.4(41.8)$ & $101.9(42.2)$ & $120.3(57)$ & $88.7(33.5)$ & $117.8(61.2)$ & 0.001 & C vs I \\
\hline Score & $20(3.7)$ & $18.4(4.1)$ & $19.1(4.3)$ & $18(3.6)$ & $19.1(3.2)$ & $19.5(3.8)$ & $15.3(4.6)$ & 0.024 & C vs I \\
\hline \multicolumn{10}{|c|}{ Visuospatial working memory } \\
\hline Level & $3(I)$ & $2.6(I . I)$ & $2.6(I . I)$ & $2.7(I)$ & $2.5(\mathrm{I} .3)$ & $2.6(1.2)$ & $2.6(1)$ & 0.002 & C vs I \\
\hline Persev err & $0.1(0.5)$ & $0.5(0.2)$ & $0(0.2)$ & $0(0.3)$ & $0(0)$ & $0(0)$ & $0.1(0.3)$ & 0.013 & C vs I \\
\hline Order err & $1.3(1.9)$ & $0.3(0.8)$ & $0.5(I)$ & $0.3(0.5)$ & $0.3(0.8)$ & $0.1(0.5)$ & $0.1(0.3)$ & 0.002 & Cvs I \\
\hline \multicolumn{10}{|l|}{ Alphabetical order } \\
\hline Essay I & I.6 (0.8) & I.8 (0.8) & I.8 (0.8) & I.6 (0.8) & $2(0.6)$ & I.7 (0.6) & $2.3(0.8)$ & NS & \\
\hline Essay 2 & $2.5(1.4)$ & $2.1(2)$ & $1.8(2.1)$ & $3(1.8)$ & $0.7(1.5)$ & $2.2(2)$ & $2(2.2)$ & NS & \\
\hline Essay 3 & $2.4(1.8)$ & $1.5(1.9)$ & $1.6(1.9)$ & $2.3(2.3)$ & $1.2(1.5)$ & $0.7(1.3)$ & $1.3(2)$ & NS & \\
\hline \multicolumn{10}{|l|}{ Subtraction I } \\
\hline Time & $95.5(71.4)$ & $79(4 \mid .4)$ & $81.3(35.2)$ & $68.2(36.9)$ & $65.6(34.1)$ & $66(27)$ & $117(65)$ & NS & \\
\hline Score & $12.2(2.4)$ & $12.9(2.4)$ & $12.5(2.3)$ & $14.2(1.2)$ & $11.6(3.1)$ & I3.8 (I.5) & II.7 (3.2) & NS & \\
\hline \multicolumn{10}{|l|}{ Subtraction 2} \\
\hline Time & $46.6(32.8)$ & $35.8(14.5)$ & $37.2(13.4)$ & 31 (13.8) & $37.6(15.1)$ & $32.4(I I .4)$ & $42.5(21.2)$ & NS & \\
\hline Score & $12.9(1.2)$ & $12.9(1.2)$ & $13.6(1.6)$ & $13.8(1)$ & $12.6(1.8)$ & $13.6(0.4)$ & $13.2(0.7)$ & NS & \\
\hline \multicolumn{10}{|l|}{ Sum } \\
\hline Time & $49.1(26.4)$ & $44.5(I 7.2)$ & $43.2(11.8)$ & $35.6(14.5)$ & $51.5(23.4)$ & $44.4(13.3)$ & $55.5(27.5)$ & NS & \\
\hline Score & $20(I)$ & $20.2(1.4)$ & $19.9(2)$ & $20.6(0.5)$ & $20.5(0.8)$ & $19.9(1.3)$ & $20.6(0.5)$ & NS & \\
\hline \multicolumn{10}{|l|}{ Maze } \\
\hline Planning err & $1.3(1.6)$ & $\mathrm{I} .3(\mathrm{I} .7)$ & $0.9(1.2)$ & $1.5(2)$ & $0.6(0.8)$ & $1.8(2.2)$ & $2.1(1.5)$ & NS & \\
\hline Time & $36.5(23.5)$ & $31.4(15.8)$ & $31.5(15.8)$ & $30.6(11.5)$ & $34(16.4)$ & $29.2(22.3)$ & $33.7(13)$ & NS & \\
\hline \multicolumn{10}{|l|}{ Mental flexibility } \\
\hline Score & $42.8(10.2)$ & $39(9.3)$ & $38(6.9)$ & $41.7(10.3)$ & $42.3(14.6)$ & $40.1(10.8)$ & $34.6(8)$ & 0.01 & C vs I \\
\hline Errors & $9.8(42)$ & $9(2.3)$ & $9.3(2.4)$ & $8.6(1.6)$ & $8(3.1)$ & $8.6(2.4)$ & $10(2.2)$ & 0.02 & C vs $E$ \\
\hline Persev err & $5.1(5.2)$ & $6.2(5.3)$ & $6.1(3.7)$ & $5.7(6.2)$ & $5.6(7.3)$ & $5.8(3.7)$ & $8.5(5)$ & & \\
\hline Criteria persev & $5.6(4.9)$ & $8.9(5.5)$ & $9.7(5)$ & $7.2(6.3)$ & $7.3(7.7)$ & $8.6(5.8)$ & $7.3(7.7)$ & & \\
\hline Maintain err & $0.6(0.8)$ & $0.6(0.7)$ & $0.6(0.8)$ & $0.6(0.6)$ & $0.5(0.8)$ & $0.7(0.9)$ & $0.3(0.5)$ & & \\
\hline Time & $379(141.4)$ & $384.8(106.3)$ & $406.5(107)$ & $324.3(80)$ & $393.1(193)$ & $383(98)$ & $390.4(89.2)$ & NS & \\
\hline \multicolumn{10}{|l|}{ Semantic classif } \\
\hline Categories & $8.7(2.9)$ & $8.4(2.7)$ & $7.7(2.5)$ & $9.2(2.4)$ & $10(5.1)$ & $8.1(2)$ & $8.2(2.5)$ & NS & \\
\hline Score & $20.6(7.4)$ & $21.4(6.5)$ & $20(6.6)$ & $22.8(7.1)$ & $24.1(6.4)$ & $21.5(6.6)$ & $21.5(6.1)$ & NS & \\
\hline \multicolumn{10}{|l|}{ Verbal fluency } \\
\hline Total & $18.8(7)$ & $16.3(7.2)$ & I $5.3(5.1)$ & 19.1 (7.4) & $16(12.2)$ & I6.I (9) & $16(5.1)$ & NS & \\
\hline Persev err & $0.8(I . I)$ & I.I (I.2) & $1.3(1.2)$ & $0.8(0.7)$ & $1.5(1.5)$ & I (I.4) & $1.2(1.4)$ & NS & \\
\hline \multicolumn{10}{|l|}{ Hanoi tower 3 rods } \\
\hline Movements & $10.4(5.5)$ & $10.3(4.8)$ & $10.1(5.2)$ & $10.9(4.2)$ & $8.1(2)$ & II (6.3) & $10.4(3.2)$ & NS & \\
\hline Time & $47(53)$ & $45(33.4)$ & $44.7(37.8)$ & $40.3(22.7)$ & $29.5(25.1)$ & $44.5(29.3)$ & $62.6(38.4)$ & NS & \\
\hline \multicolumn{10}{|l|}{ Hanoi tower 4 rods } \\
\hline Movements & $27.2(12.8)$ & $27.5(12)$ & $25.9(10.7)$ & 29.7 (19) & 33.6 (II.5) & $26(8.8)$ & 27.1 (8.5) & NS & \\
\hline Time & $120(40.5)$ & $118.6(68.7)$ & $116(48.9)$ & $112(30.8)$ & $111(38.6)$ & $115(29)$ & $134(35.4)$ & NS & \\
\hline
\end{tabular}

Note: Standard deviations are presented in parentheses.

Abbreviations: C, controls; E, enforcers; I, inmates; NS, not significant; SD, standard deviation; Sig dif, significant differences.

\section{Discussion}

Studying criminal profiles presenting different typologies and psychopathic and sociopathic traits provides a valuable opportunity to understand the neurobiology of violent behavior. We obtained a valuable characterization of the psychopathic, sociopathic, and neuropsychological traits in a delinquent sample convicted for violent and nonviolent crimes related to drug traffic.
First, only the kingpins and enforcers can be considered psychopaths, while the rest of them can be classified as having a medium-high psychopathy level that is in line with their crime history and actions as members of a criminal organization. These features define their harsh role in the criminal organization, in which such "cold-bloodedness" is required to engage in violent activities - either directing and/or perpetrating them - that 


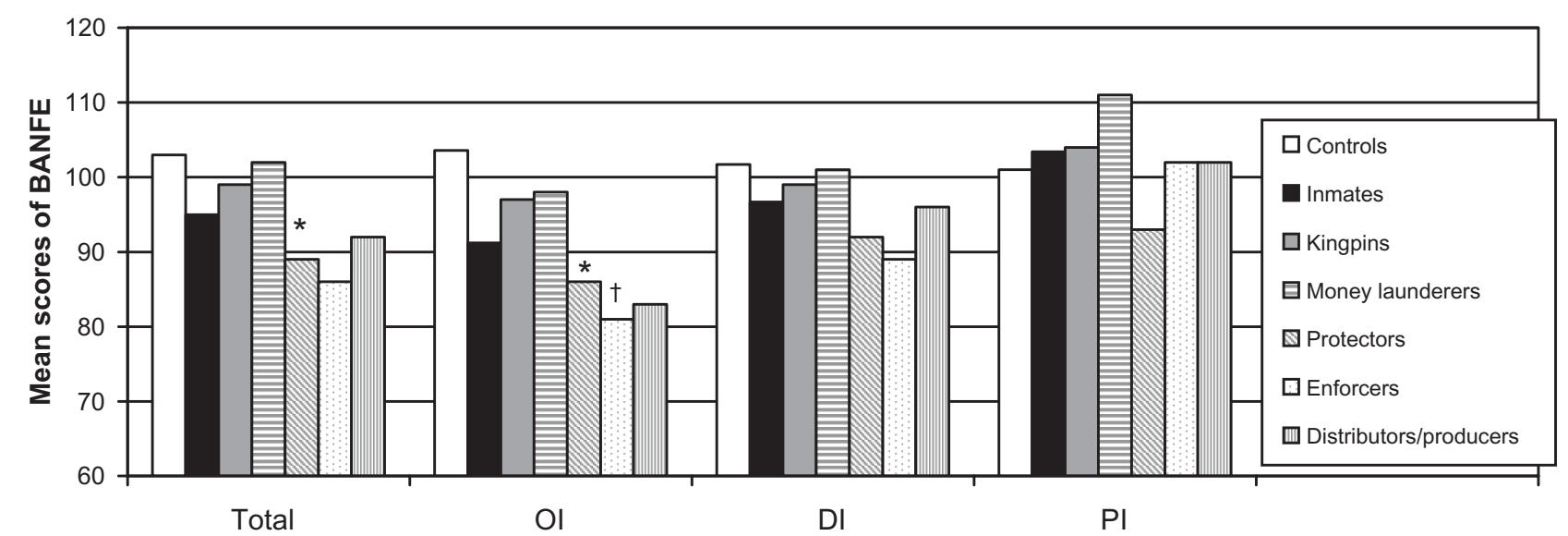

Figure 2 Mean scores of the Executive Functions Battery and indexes by groups. Notes: $P \leq 0.05$; *controls vs enforcers; ${ }^{\dagger}$ controls vs distributors/producers.

Abbreviations: OI, orbitomedial index; DI, dorsolateral index; PI, Anterior prefrontal index.

have a tremendous negative impact on the lives of others as well as society.

Our groups show interesting contrasts, in which kingpins, enforcers, and money launderers displayed the core features of psychopathy, portraying lack of empathy, cruelty, glibness, and callousness to a higher extent, while the money launderers and protectors failed to present the same antisocial lifestyle components or other prevailing delinquent habits as other types of criminals. These contrasts may reflect the ability of the two groups to be socially functional despite living a double life without participating directly in violent acts. It is worth noting the contrast found in the money launderers, who present a higher level of education, increased interpersonal and affective detriments, and low antisocial traits, findings which are in accordance with those of the "successful psychopaths." 39,40 These individuals maintain a relatively normal lifestyle, but they lack affective bonds, have increased arrogance, callousness, and a strong desire for recognition, as well as a desire to attain a certain economic status, ${ }^{41,42}$ traits that allow them to achieve their goals through unethical and illicit nonviolent activities. Although the protectors may present more affective bonds than money launderers, they are prone to elicit more antisocial and violent acts. The enforcers present a similar psychopathic profile to that of the kingpins, but a higher trend to elicit antisocial acts was observed, the latter being the criminal minds behind the violent actions and probably still directing them from behind bars. Additionally, it may be the case that a frontal lobe dysfunction underlies the enforcers' behavior, which prevents them from "succeeding" in their criminal career and differentiates them from the kingpins, as discussed below. Finally, the distributors/producers showed the fewest affective impairments and an average antisocial lifestyle, which would define them as a prototypic criminal, able to commit physical assaults for immediate gratification. It should be noted that their F2 PCL-R scores were still twice as high as those in the control group.

In general, the executive functioning of the groups was within normal range, except for the enforcers, who performed significantly lower than the controls and just above the normal-low level. Interestingly, it is the orbitofrontal cortex frontal area that presents functional deficits in this sample and correlates with psychopathy, probably underlying their abnormal social behavior, inability to learn from previous experiences, and negative outcomes of their actions, and a marked failure in decision-making characterized by the need for immediate gratification regardless of potential prosecution. The enforcers also lacked proper inhibition, thus enhancing the elicitation of impulsive and highly aggressive and violent crimes when compared with the other criminal groups. The distributors/producers would in turn, be regarded as a group whose orbitofrontal dysfunction prevents them from making advantageous decisions different from delinquency to obtain immediate economic benefits. But they presented an adequate inhibition that prevents them from eliciting violent acts. It is worth noting the higher performance of money launderers, represented by the Anterior Prefrontal Index, probably reflecting the cognitive resources to manage a "double life," running a multimillion-dollar illegal business while still adapting to society. Our study did not confirm dorsolateral functioning detriments in the criminal sample as in previous studies; however, these may occur due to the conditions of isolation in which they are kept, diminishing cognitive abilities such as working memory, planning, and mental flexibility. 
In conclusion, a generalized frontal dysfunction in the criminals cannot be stated, despite a trend of lower functioning than nondelinquent individuals; however, psychopathic traits are strongly correlated with orbitofrontal functioning. It is important to observe the role that this area plays in delinquent behavior, and specially in violent offenders, meaning that it may be one of the neurobiological underpinnings that led them to carry out the aggressive and violent acts they were hired for, engaged into or established as a highly profitable modus vivendi, threatening an entire society and risking the security of their families in most cases, and affecting thousands of people in exchange for financial benefits.

Finally, we must encourage the potential advantages of applying neuropsychological frontal assessments in courts when examining unimpaired offenders, in whom the performance can reflect their criminal capacity and probably their psychopathic traits, although this relationship must be further studied. Neuropsychological examinations have the advantage of being an objective measurement of frontal lobe functioning, which has been extensively related to antisocial behavior, and may provide clearer evidence than subjective examinations while decreasing malingering.

The vast majority of incarcerated offenders belonged to a primary familial group of low socioeconomic income and reported that the main reason for dropping out of school was to contribute to the family expenses and/or to improve their socioeconomic level. Additionally, it was reported that since their adolescent years, a noticeable interest and motivation oriented towards acquiring material possessions that clearly exhibit wealth (luxurious cars, ostentatious jewelry, recognizable fashion brand names) worked as a potential factor in their search for a higher economic income. Given their high psychopathic traits and low orbitofrontal functions, these were determinant to have a bearing on the illegal activities that helped them to reach their desired socioeconomic status.

During the interview, it was observed that in the subjects' social circles, there was high acceptance of these illegal activities and lifestyles, not only for the economic profits these activities represent for the individuals themselves but also for their families, their social acquaintances, and their geographic setting.

It was found that there was a neuropsychological and behavioral profile that typifies offenders related to drug cartels, and that these individuals may be clearly identified through the Battery of Executive Functions and with the use of psychopathy scales. This profile may be of great use in determining the cognitive abilities and the background of criminals. This in turn will reveal their role within the criminal organization as well as identify their level of psychopathy and emotional deficits reflected by their violent actions.

An objective classification of incarcerated criminals will allow us to distinguish between neuronal and cultural psychopaths and sociopaths ${ }^{10}$ and will help us to establish adequate rehabilitation programs.

In other words, nowadays there are few possibilities for readaptation of psychopaths. For the sociopaths, on the other hand, it is possible to apply therapies that provide training in cognitive abilities in order for them to understand the thoughts and feelings of others, and to expand their world vision and figure out new interpretations of rules and social obligations. Indeed, we must teach them how to understand the feelings of others, taking into account that this precise inability to feel the emotions of others gives these criminals their ultimate reason to act the way they do.

Every phenotype is made of genetic and environmental contributions, as previously reviewed. Beaver and Barnes ${ }^{31}$ reported that drug-selling behaviors had a significant genetic influence, and concluded that the genetic factors in drugselling behaviors may be stronger for those who are actively involved in the drug trade and generate a significant amount of income from selling drugs, while occasionally dealers may be less affected by genetic factors and more affected by environmental ones. According to their study, $31 \%$ of the variance was the result of non shared environmental effects, which could suggest that the etiologic pathways of the different antisocial behaviors within organized crime may be influenced by the selection of environment, such as in our subjects, for whom there existed a broad acceptance and validation of lifestyles characterized by the accumulation and display of material values over intellectual and social values, which in addition to drug consumption potentiates the development of aggressive, violent, and antisocial personalities.

Thus, readaptation must be addressed in programs that strengthen cognitive abilities that are normally diminished in these individuals. These programs must encourage a lifestyle with an "integral wealth" concept: where wealth is not viewed only in terms of economic resources but also includes personal, social, familial, labor, and cultural assets. The programs should also provide technical or professional activities that improve standard of living through socially accepted means.

For prevention, it is necessary to target these types of programs at sectors with high crime, such as the less 
economically favored provinces, popular neighborhoods, or population sectors where domestic violence plays an important role in the development of these individuals.

Briefly, criminality syndrome is a product of biologic predispositions, including those of genetic origin, to carry out, for example, impulsive and violent actions, as well as interactions with psychological and social factors. Physiological processes are the bases that limit the biological substrate over which the environment exerts its influence.

\section{Acknowledgments}

We would like to thank Jaime Rivera for his support while conducting this research and Martha Luisa Perez for reviewing the English translation.

\section{Disclosure}

The authors report no conflicts of interest in this work.

\section{References}

1. Vilalta C. Death Patterns and trends related to organized crime. Faculty of Urban and Regional Planning. Autonomuos University of Mexico. April 26, 2011; Mexico City, Mexico.

2. Cook CW. Mexico's Drug Cartels. CRS Report for Congress. Washington: Foreign Affairs, Defense, and Trade Division; 2007.

3. CISEN.gob [homepage on the Internet]. México: Centro de Investigación y Seguridad Nacional. Available from: http://www.cisen. gob.mx. Accessed July 31, 2012.

4. Abram KM. The effect of co-occurring disorders on criminal careers: interaction of antisocial personality, alcoholism, and drug disorders. Int J Law Psychiatry. 1989;12:133-148.

5. Moffitt TE. Neuropsychology and self-reported early delinquency in an unselected birth cohort: a preliminary report from New Zealand. In: Moffitt TE, Mednick SA, editors. Biological Contributions to Crime Causation. Dordrecht: Martinus Nijhoff; 1988: 93-117.

6. American Psychiatric Association. Diagnostic and Statistical Manual of Mental Disorders. 4th ed. Arlington: American Psychiatric Publishing; 2000.

7. Ostrosky F. Killer Minds: The violence in your brain. 2nd ed. Mexico: Qúo Libros; 2011.

8. Hare RD. The Hare Psychopathy Checklist-Revised. Toronto: MultiHealth Systems; 1991.

9. Ostrosky F, Ruíz H, Arias N, Vásquez V. Standardization of PCL-R in mexican inmates sample. Rev Neuropsicol Neuropsiquiatría Neuroci. 2008;8:49-58.

10. Tovar J, Ostrosky F. The Construction of Moral Judgement: Neurobiology and Philosophy. Mexico: Manual Moderno; In press 2012.

11. Blair RJR. The amygdala and ventromedial prefrontal cortex in morality and psychopathy. Trends Cogn Sci. 2007;11:387-392.

12. Viding E, Blair J, Moffit T, Plomin R. Evidence for substantial genetic risk for psychopathy in 7-year-olds. J Child Psychol Psychiatry. 2005;46: 592-597.

13. Tranel D. Acquired sociopathy: the development of sociopathic behavior following focal brain damage. In: Fowles DC, Sutker P, Goodman HS, editors. Progress in Experimental Personality and Psychopathology. New York: Springer; 1994:285-311.

14. Saver JL, Damasio AR. Preserved access and processing of social knowledge in a patient with acquired sociopathy due to ventromedial frontal damage. Neuropsychologia. 1991;29:1241-1249.
15. Blumer D, Benson D. Personality changes with frontal and temporal lobe lesions. In: Benson D, Blumer D. editors. Psychiatric Aspects of Neurologic Disease. New York: Grune and Stratton; 1975.

16. Damasio AR, Tranel D, Damasio H. Individuals with sociopathic behavior caused by frontal damage fail to respond automatically to social stimuli. Behav Brain Res. 1990;41:81-94.

17. Borja K, Ostrosky F. Early traumatic events in psychopaths. J Forensic Sci. In press 2012.

18. Yang Y, Raine A, Colletti P, Toga AW, Narr KL. Abnormal temporal and prefrontal cortical gray matter thinning in psychopaths. Mol Psychiatry. 2009;14:561-562.

19. Raine A, Lencz T, Bihrle S, Lacasse L, Colletti P. Reduced prefrontal gray matter volume and reduced autonomic activity in antisocial personality disorder. Arch Gen Psychiatry. 2000;57:119-127.

20. Raine A, Ishikawa S, Arce E, et al. Hippocampal structural asymmetry in unsuccessful psychopaths. Biol Psychiatry. 2004;55:185-191.

21. Tiihonen J, Hodgins S, Vaurio O, et al. Amygdaloid volume loss in psychopathy. Abstr Soc Neurosci. 2000:2017.

22. Raine A, Meloy J, Bihrle S, Stoddard J, LaCasse L, Buchsbaum MS. Reduced prefrontal and increased subcortical brain functioning assessed using positron emission tomography in predatory and affective murderers. Behav Sci Law. 1998;16:319-332.

23. Anderson SW, Bechara A, Damásio H, Tranel D, Damasio AR. Impairment of social and moral behavior related to early damage in human prefrontal cortex. Nat Neurosci. 1999;2:1032-1037.

24. Mitchell DGV, Colledge E, Leonard A, Blair RJR. Risky decisions and response reversal: is there evidence of orbitofrontal cortex dysfunction in psychopathic individuals? Neuropsychologia. 2002;40: 2013-2022.

25. Lapierre D, Braun C, Hodgins S. Ventral frontal deficits in psychopathy: neuropsychological test findings. Neuropsychologia.1995;33: 139-151.

26. Dinn WM, Harris CL. Neurocognitive function in antisocial personality disorder. Psychiatry Res. 2000;97:173-190.

27. Pham TH, Vanderstukken O, Philippot P, Vanderlinden M. Selective attention and executive functions deficits among criminal psychopaths. Aggress Behav. 2003;29:393-405.

28. Dolan M, Park I. The neuropsychology of antisocial personality disorder. Psychol Med. 2002;32:417-427.

29. Hare RD. Manual for the Revised Psychopathy Checklist. 2nd ed. Toronto: Multi-Health Systems; 2003.

30. Arias N, Ostrosky F. Neuropsychological assessment in mexican inmates. Rev Chil Neuropsicol. 2010;5:113-127.

31. Beaver KM, Barnes JC. Admission of drug-selling behaviors is structured by genetic and nonshared environmental factors: results from a longitudinal twin-based study. Addict Behav. 2012;37:697-702.

32. Morgan AB, Lilienfeld SO. A meta-analytic review of the relation between antisocial behavior and neuropsychological measures of executive function. Clin Psychol Rev. 2000;20:113-136.

33. Sheehan D, Lecrubier Y, Sheenah H, et al. The Mini-International Neuropsychitric Interview (M.I.N.I): the development and validation of a structured diagnostic psychiatric interview for DSM-IV and ICD-10. J Clin Psychiatry. 1998;59:22-33.

34. Ishikawa SS, Raine A, Lencz T, Bihrle S, Lacasse L. Autonomic stress reactivity and executive functions in successful and unsuccessful criminal psychopaths from the community. J Abnorm Psychol. 2001; 110:423-432.

35. Penteado H, Arboleda-Florez J, Portela F. Identifying the cut-off score for the PCL-R scale (psychopathy checklist - revised) in a Brazilian forensic population. Forensic Sci Int. 2005;147:1-8.

36. Flores JC, Ostrosky F, Lozano A. Battery of Frontal and Executive Functions (BANFE). Mexico: Manual Moderno; 2012.

37. Lezak MD, Howieson DB, Loring DW. Neuropsychological Evaluation. 4th ed. New York: Oxford University Press; 2004.

38. Bremner JD, Vermetten E, Mazure C. Development and preliminary properties of an instrument for the measurement of childhood trauma: The early trauma inventory. Depress Anxiety. 2000;12:1-12. 
39. Widom CS, Newman JP. Characteristics of non-institutionalized psychopaths. In: Farrington DP, Gunn J, editors. Aggression and Dangerousness. New York: Wiley; 1985:57-80.

40. Gao Y, Raine A. Successful and unsuccessful psychopaths: a neurobiological model. Behav Sci Law. 2010;28:194-210.
41. Sutker PB, Allain AN. Behavior and personality assessment in men labeled adaptive sociopaths. J Psychopathol Behav Assess. 1983;5: 65-79.

42. Mullins-Sweatt SN, Glover NG, Derefinko KJ, Miller JD, Widiger TA. The search for the successful psychopath. J Res Pers. 2010;44: 554-558.

\section{Publish your work in this journal}

Research and Reports in Forensic Medical Science is an international, peer-reviewed, open access journal publishing original research, reports, reviews and commentaries on all areas of forensic medical science. The manuscript management system is completely online and includes a very quick and fair peer-review system. Visit http://www.dovepress.com/ testimonials.php to read real quotes from published authors. 